\title{
PERJUMPAAN AGAMA DAN TRADISI MASYARAKAT SULAWESI SELATAN: BACAAN TERHADAP BUKU ISLAMISASI BUGIS
}

\author{
Ismail Suardi Wekke \\ Sekolah Tinggi Agama Islam Negeri (STAIN) Sorong \\ Email: ismail@stain-sorong.ac.id
}

\begin{abstract}
ABSTRAK
Artikel ini catatan dalam membaca buku Islamisasi Bugis tulisan Andi Muhammad Akhmar terbitan Yayasan Pustaka Obor Indonesia. Buku ini merupakan kajian sastra la Galigo untuk versi Bottinna I La Dewata Sibawa I We Attaweq.
\end{abstract}

Kata Kunci: Islam, Bugis, Adat.

\section{PENDAHULUAN}

Walaupun bukan agama pertama yang dikenal di Sulawesi Selatan, ketika itu masih kerajaan, namun Islam dianut secara meluas di semua kota dan kabupaten. Tidak terkecuali Kabupaten Tana Toraja, dan Toraja Utara. Bahkan masyarakat Bugis identik dengan Islam, walau saja ada kelompok-kelompok masyarakat Bugis di Bone dan Soppeng yang menganut Katolik. Dengan demikian, terdapat perjumpaan agama lain setelah kepercayaan animisme sebelum Islam diterima oleh pelbagai kalangan di Sulawesi Selatan.

Sastra menjadi media mengenalkan Islam (hal. 8). Sehingga walaupun di fase awal Islam menempuh dua jalur perkenalan, namun dalam perkembangan selanjutnya kemudian tersosialisasi tidak saja dalam bentuk formal pembelajaran tetapi juga dikenalkan melalui sastra. Artikel bertujuan untuk menggambarkan hasil bacaan terhadap buku Islamisasi Bugis (Akhmar, 2018).

\section{ISLAMISASI BUGIS}

Buku ini merupakan kajian sastra untuk naskah La Galigo dengan fragmen Bottinna La Dewata Sibawa I We Attaweq (BDA). Buku ini tidak hanya menganalisis satu naskah saja, tetapi terdapat empat belas naskah lain yang dianalisis (hal. 466). Sehingga ada sebuah narasi yang komprehensif untuk menggambarkan kelengkapan versi BDA sebagai sebuah cerita yang lengkap.

Naskah BDA ditulis setelah masuknya Islam di Sulawesi Selatan. Ini bisa terlihat dengan uraian khusus dalam buku tentang kewujudan bahasa Arab dalam penulisan naskah 
(hal. 507). Sepanjang penulisan naskah mulai dari halaman awal memuat terma-terma yang berasal dari praktik keberagamaan dalam Islam. Ini menunjukkan bahwa periodesasi penulisan naskah BDA sepenuhnya dilakukan setelah masyarakat Bugis menerima Islam sebagai agama. Hanya episode BDA dalam keseluruhan rangkaian La Galigo yang secara khusus menggambarkan adanya pengaruh Islam (hal. 5). Inilah yang disebut oleh AKhmar sebagai keunikan tersendiri BDA sehingga dipilih untuk dianalisis dalam kaitan Islam di tanah Bugis.

Buku ini juga menggambarkan bahwa Islam tidaklah diterima secara damai saja (hal. 1). Itu hanya untuk di fase awal. Selanjutnya kerajaan Gowa mengajak kerajaan lain untuk memeluk Islam. Hanya saja, terdapat penolakan. Sehingga dua kerajaan diperangi untuk tunduk menerima Islam yaitu Kerajaan Sidenreng Rappang dan Kerajaan Soppeng.

\section{KONSTRUKSI TEORITIS}

Di awal paparan buku, menggambarkan masuknya Islam di kerajaan-kerajaan Makassar dan Bugi, saat ini disebut Provinsi Sulawesi Selatan. Sehingga terdapat dua pola pengislaman yaitu melalui jalur perdagangan dan juga perang (musuq selleng). Penyebaran Islam juga mendapatkan keterlibatan ulama-ulama Minangkabau dengan kehadiran tiga datuk: Datuk Sulaiman, Datuk Ribandang, dan Datuk Patimang. Setelah penerimaan Islam, masayarakat Bugis kemudian mengejawantahkan Islam dalam pelbagai aspek kehidupan, salah satunya dalam bidang sastra (Akhmar, 2017). Termasuk pula dalam soal penamaan. Adaptasi nama Arab ke dalam pelafalan masyarakat Bugis diadaptasi (Abidin, 2016). Begitu pula dengan bangunan dan arsitektur (Wasilah, Sabri, Ikhsan, \& Wekke, 2017).

Bisa pula bukan hanya Islamisasi Bugis, tetapi juga wujud Bugisisasi Islam (hal. 506). Beberapa kosakata Bugis kemudian tetap dijadikan sebagai terma-terma dalam percakapan seperti Dewata Seuwae, Lamarupe, dll. Kesemuanya sesusngguhnya sudah wujud sebelum datangnya Islam. Setelah perjumpaan dengan Islam, kosakata tersebut tetap digunakan. Hanya saja dengan muatan ideologis Islam. Begitu pula dengan percakapan soal korupsi (Wekke \& Yusuf, 2018; Yusuf \& Wekke, 2017), adopsi anak (Yusuf \& Wekke, 2019), warisan (Yusuf \& Wekke, 2018).

Masyarakat Bugis menempatkan Islam sebagai salah satu pilar masyarakat (Wekke, 2017a). Dalam perkembangannya, Islam dan adat tidak saling mematikan. Justru tetap dapat berdampingan. Pola perjumpaan ini dengan penerimaan Islam sebagai agama dan 
kepercayaan. Saat merantaupun, masayarakat Bugis tetap saja mempertahankan pola keislaman dengan corak ada yang dianutnya (Wekke, 2014; Wekke, 2017b, Wekke, 2015).

Namun demikian, perlu dicatat bahwa bukan saja Islam yang diterima oleh masyarakat Bugis. Tetapi juga Katolik (Arafah, 2017). Ekspresi beragama masyarakat Bugis yang kemudian dijadikan pokok bahasa buku ini hanya pada Islam, dengan obyek karya sastra La Galigo dalam versi BDA.

\section{PENUTUP}

Sebagai buku yang dihasilkan dari disertasi, buku Islamisasi Bugis merupakan karya yang mendekati sempurna. Catatan ini didasarkan bahwa kelengkapan data dan juga cakupan analisis menyajikan data yang lengkap. Sementara itu, buku Islamisasi Bugis mengalami review dengan tahapan yang berjenjang sehingga menghasilkan sebuah karya yang hampir paripurna, kalau tidak bisa dikatakan paripurna.

\section{DAFTAR PUSTAKA}

Abidin, A. (2016). Pengaruh Islam Dalam Perubahan Nama Diri Suku Bugis: Sebuah Tinjauan Sejarah. IBDA: Jurnal Kajian Islam dan Budaya, 14(2), 241-253.

Akhmar, A. M (2018). Islamisasi Bugis. Jakarta: Yayasan Pustaka Obor.

Akhmar, A. M. (2017). Sastra Sebagai Sarana Islamisasi Bugis; Telaah Filologi dan Semiotik atas Karya Sastra Bugis Saduran.

Arafah, S. (2017). Islam dan Kristen Di Tanah Bugis Soppeng (Sejarah Dan Perkembangannya). PUSAKA, 5(2), 151-164.

Wasilah, W., Sabri, M., Ikhsan, M., \& Wekke, I. S. (2017). Acculturation Bugis-Makassar and Islamic Belief In Building Township Tallo Indonesia.

Wekke, I. S. (2014). Islam dan Adat dalam Pernikahan Masyarakat Bugis di Papua Barat. THAQAFIYYAT: Jurnal Bahasa, Peradaban dan Informasi Islam, 13(2).

Wekke, I. S. (2015). Arabian society in Kaili lands, central Sulawesi: Arabic education and its movement. Tawarikh, 7(1).

Wekke, I. S. (2017a). Islam dan adat: tinjauan akulturasi budaya dan agama dalam masyarakat Bugis. Analisis: Jurnal Studi Keislaman, 13(1), 27-56.

Wekke, I. S. (2017b). Migrasi Bugis dan Madura di Selatan Papua Barat: Perjumpaan Etnis dan Agama di Minoritas Muslim. Intelektualita, 6(2), 163-180.

Wekke, I. S., \& Yusuf, M. (2018). The Corruption in Religious Text and Local Wisdom Perspectives in Bugis Society. IBDA: Jurnal Kajian Islam dan Budaya, 16(1).

Yusuf, M., \& Wekke, I. S. (2017). Korupsi Dari Perspektif Alquran dan Kearifan Lokal: Penyebab, Dampak, dan Pencegahannya.

Yusuf, M., \& Wekke, I. S. (2018). Inheritance and Gender Equality. Justicia Islamica, 15(1).

Yusuf, M., \& Wekke, I. S. (2019). Child Adoption Practices in the Bugis Community: Between Bugis Tradition and Ulama Views. AL-'ADALAH, 15(1), 73-100. 